\title{
Villa Tugendhat as a Technical Monument - Elements of Passive Solar Architecture
}

\author{
L. Maurerová, J. Hirš
}

\begin{abstract}
The elements of passive solar architecture are crucial for designing of low-energy and passive houses; moreover it might be surprising that some of the principles of passive solar architecture were applied in the functionalist Villa Tugendhat built in the year 1930, designed by the German architect Ludwig Miese van der Rohe and which belongs to the UNESCO World Heritage List.
\end{abstract}

This case study attempts to point out the individual elements of solar architecture which were applied in the villa. In order to verify some of the statements/claims a numerical simulation of incident solar radiation (XSun) was performed in the Danish simulation software BSim. The paper includes a list of other timeless technical specifics, especially in terms of HVAC, which were used in the villa, and the authors have written about elsewhere (Villa Tugendhat - An Unique Air-conditioning System in Residential Hall. CLIMA 2013. ISBN 978-80-260-4001-9).

Keywords-villa Tugendhat; technical monument; building services; passive solar architecture; BSim; case study

\section{INTRODUCTION}

Born in Germany the architect Ludwig Mies van der Rohe is considered as pioneer of the so "modern architecture" or also the architecture of "skin and bones". Buildings reflecting his genius can be found not only in Europe, but also in the USA where he spent certain part of his life. One of his masterpieces is the villa of the Tugendhat family located in the Moravian metropolis Brno, the Czech Republic. Villa Tugendhat represents a combination of modern architecture and hi-tech technologies of that time. The central part of this paper is a case study which focuses on the elements of passive solar architecture integrated in this structure.

\section{LUDWIG MIES VAN DER ROHE}

Ludwig Mies van der Rohe the architect of German origin was born on March $29^{\text {th }} 1886$ in Aachen (Germany) and he died on August $17^{\text {th }} 1969$ in Chicago (USA). His life could be divided into two phases when the milestone being the year 1938. Before this year he lived and worked in Europe, mostly in Germany. There he worked as an architect as well as a pedagogue and the director Bauhaus school in Dessau. After the year 1938 he was forced to emigrate to the USA; he settled in Chicago where he worked as the architect as well as he taught architecture at the Illinois Institute of Technology. [1] [2]
Mies's famous works from the European phase include: participation at the Weissenhofsiedlung housing estate project (1927, Stuttgart, Germany), the German pavilion at the international Barcelona exhibition known as the Barcelona pavilion (1928 - 1930, Barcelona, Spain) and Villa Tugendhat (1928 - 1930, Brno, Czech Republic - Fig. 1). [1] [2]

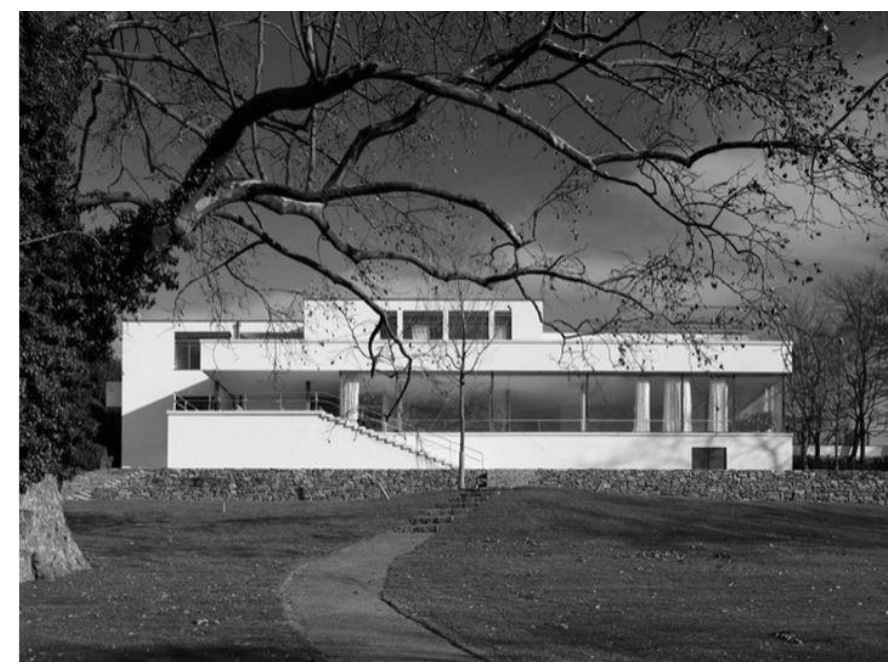

Figure 1. Photography of Villa Tugendhat south-west elevation from the garden [source: David Židlický [3]]

His masterpieces from the American phase include: Farsworth House (1947, Illinois, Chicago - USA), in the cooperation with Herbert Greenwald he designed the Lake Shore Drive 860 and 880 apartments (1948, Illinois, Chicago USA), the Crown Hall pavilion as a part of the university campus of the Illinois Institute of Technology (1956, Illinois, Chicago - USA) and the high-rise Seagram Buildings (1954 1958, Manhattan, New York City - USA). [1] [2]

His last works is the cooperation on the Neue Nationalgalerie (1967, Berlin, Germany). [1] [2]

\section{VILLA TUGENDHAT}

\section{A. The Key Moments in the History of Villa}

The functionalist villa Tugendhat (Fig. 1) is such a wellknown building that it does not need a long introduction but let us remind just a few key moments from its history. Villa Tugendhat was designed in the studio of German architect Ludwig Mies van der Rohe. It was built for the family of Greta 
and Fritz Tugendhat who lived there from the year 1930 (when the villa was completed) to 1938 (when the family had to emigrate). In the following years there were Gestapo (1939), Soviet army (1945), the dance school (until 1950) and physiotherapy gym (after 1950). In 1963 it was put on the state list of real estate cultural monuments. The first renovation was undertaken in the years 1982 - 1985. In 1995 it was given the status of National Cultural Monument, and in 2001 it was put on the UNESCO List of World Heritage Site. The second large renovation of the villa started in 2010 and the grand reopening was held in March 2012. This renovation brought villa into the form as it was in the years 1930 - 1938. [4] [5] [6]

\section{B. Special High Technologies}

Apart from the perfect architecture the villa has exceptional service and technical amenities: especially the timeless system of large sash windows in the living space driven by the electric motor, and a unique air-condition system which treated the air in the living space (it enabled heating, cooling and humidification at the same time). Among other unconventional and timeless services were included: service lift, kitchen lift, photocell light motion sensor at the terrace, or the rainwater tank in the basement. [6]

\section{PASSIVE SOLAR ARCHITECTURE}

\section{A. Principle}

The term "passive solar architecture" refers to the discipline which focuses on heating and cooling of buildings by using passive solar energy. The principle of passive solar energy is to use the solar energy directly without any technical devices (active components). Predominantly it is the so called "greenhouse effect" when the sun beams enter the glass parts of buildings and the heat accumulates in the structure and objects in the rooms. The ancient Greek philosopher Socrates designed a house which maximized the potential of solar energy gains in winter and minimized overheating in summer. This house which was designed corresponding exactly to the heights and azimuths of the sun in the course of a day and a year is called "Socrates' House" and its principles have been used up to now. (see Fig 2). [6]

Ground plan of Socrates' house

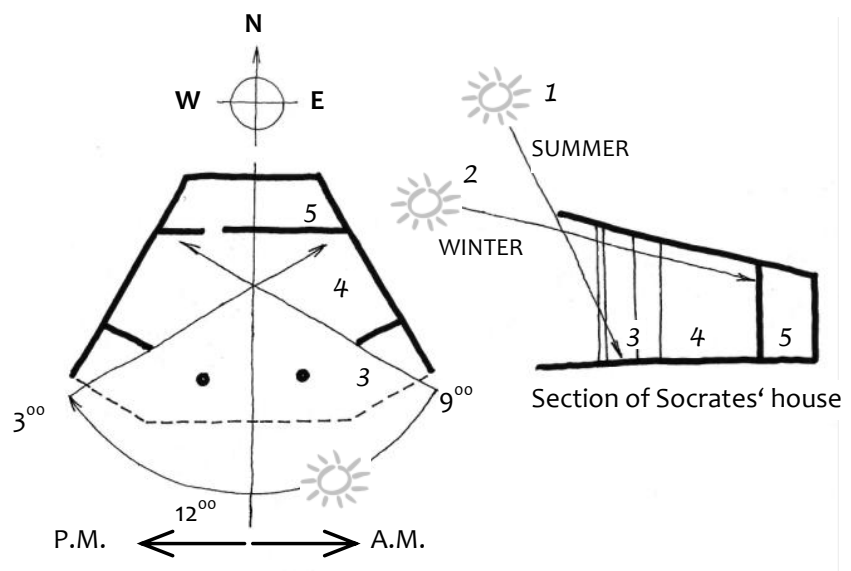

Figure 2. Schema of Socrates' house (1 - position of sun in summer, 2 position of sun in winter, 3 - entrance hall (southern buffer zone), 4 - living area (the core of the house), 5 - store room (northern buffer zone)) [7] [8]

\section{B. Components of Passive Solar Architecture}

Let us concentrate on characteristic elements of passive solar architecture, namely the following passive elements [6]:

- Placement of a building into terrain and its ideal solar orientation;

- The size and orientation of glazed (translucent) area the largest glazed areas placed on the south, south-east or south-west facade; winter garden on the east or west side; while on the north facade we possibly do not place any, or very small glazed areas;

- A selection of suitable shading components (solar screen, Venetian blinds, awnings, roller blinds, shutters, anti-reflective coating, curtains and drapery, greenery) contribute to the minimization of unwanted solar gains in summer;

- Creation of accumulation cores in buildings: consists in the suitable composition of structures where thermal mass is mostly represented by concrete, on the exterior it is a sufficient layer of thermal insulation;

- Plan thermal zoning, based on the rooms layout in the Socrates' house, the living area is oriented to the south and in the core of the house; the north side houses dressing rooms, bathrooms, storerooms, utility rooms, etc.

Apart from the above mentioned basic passive elements, the passive solar architecture includes solar walls collectors (Trombe wall), solar chimneys, or double-skin facades and roofs (air collectors fitted into the facades and roofs). [6]

\section{CASE Study}

\section{A. The Aim and Methods of Case Study}

The aim of the case study was to prove that the above mentioned elements and principles of passive solar architecture were applied in the design and realization of Villa Tugendhat.

The method used is analytic - a comparison of the analogy between the general passive solar architecture elements and the specific elements which were indicated in Villa Tugendhat; and also the method of numeric simulation of the incident solar radiation in the main living space, performed in the Danish simulation software BSim [9].

\section{B. The Elements of Passive Solar Architecture in Villa Tugendhat}

If we consider the above-mentioned basic elements of solar architecture, it is surprising that almost all of them could be found in Villa Tugendhat:

1) Building orientation: In Fig. 3 we can see a crosssection of Villa Tugendhat. The building is set in a sloping terrain. It complies with the rule of orientation where the north- 
east part of building is set in the slope (only the upper floor is above the terrain) which helps to minimize the heat losses - the soil serves as insulation. While the south-west part of building is open (all three floors are above the terrain) and maximizes solar gains. [6] landlord, of the lady, of the children, of the governess, living space and kitchen) form the southern buffer zone and partly the core of the building. The northern buffer zone is formed by utility and technical rooms (staircase, bathrooms, toilet, dressing rooms, food store, corridors).

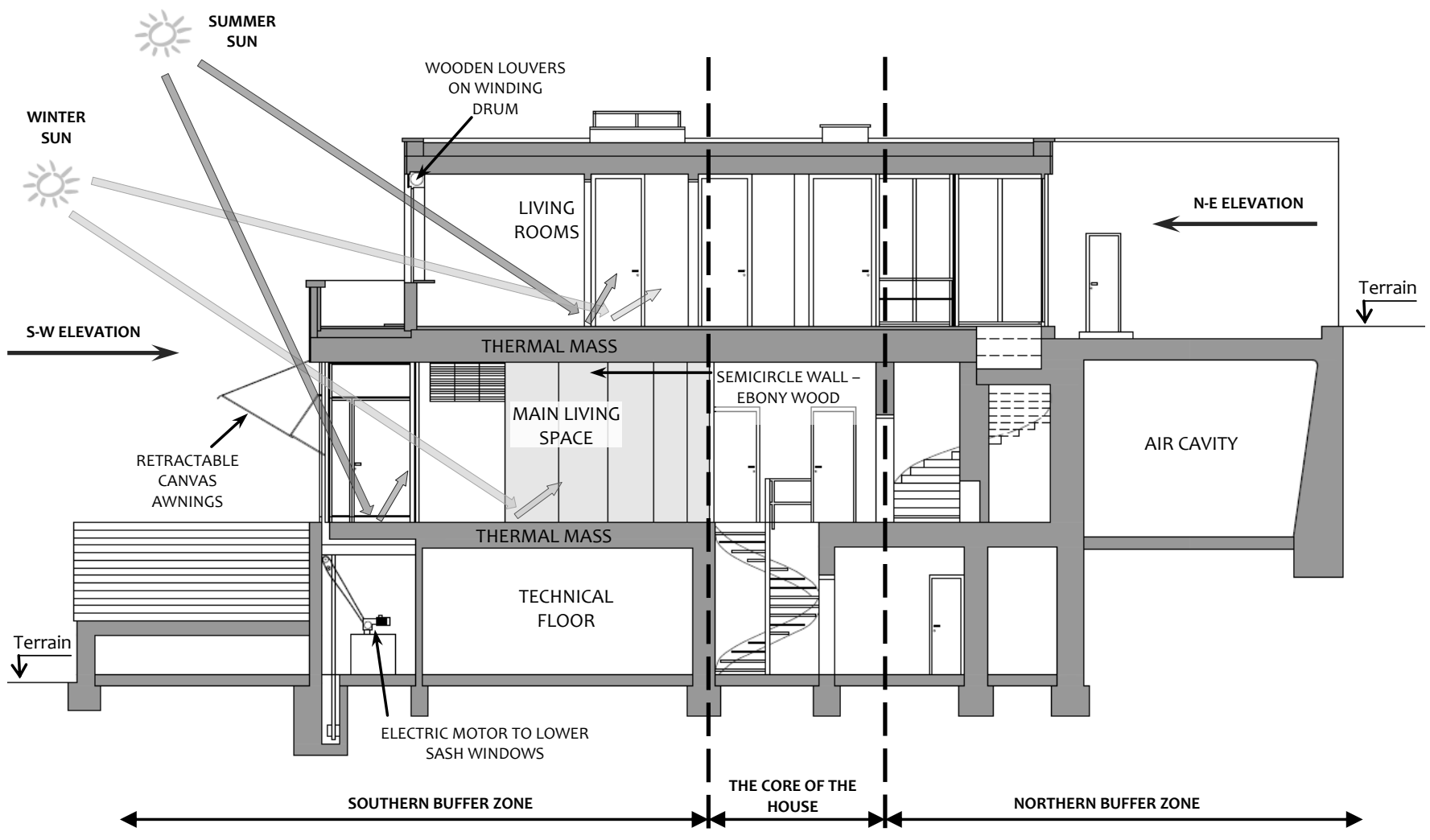

Figure 3. Section of Villa Tugendhat-elements of passive solar architecture indicated [source: author]

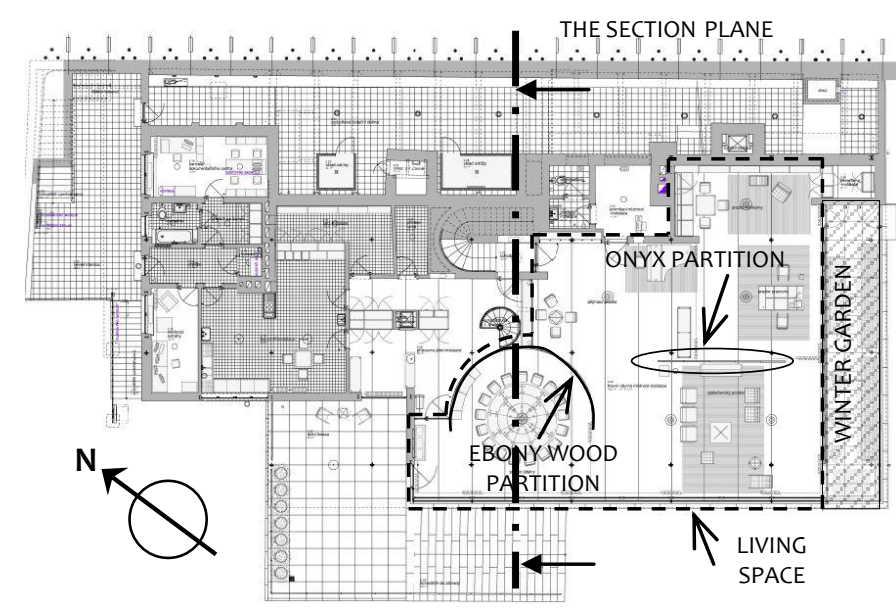

Figure 4. Ground plan of first floor - the living space indicated by dashed line; the winter garden indicated by rectangle with infill; the onyx wall indicated by ellipsis and ebony partition [source: author]

2) Plan thermal zoning: With reference to the Socrates' house, let us compare it with the section in Fig. 3. The villa again complies with the rule of living rooms (the room of the
The basement serves as a technical floor. [6]

3) Shading elements: The shading elements are placed on the windows facing south-west. On the top floor the shading elements are wooden louvres on winding drum placed on the windows of all rooms (see Fig. 3). The windows of the living space are provided with retractable canvas awnings (when fully extended they form about $60^{\circ}$ angle with the window level - see Fig. 3). Further shading is provided by the deciduous trees planted at the south-east side of the building (they shade the glazed side with the winter garden). [6]

4) Internal thermal mass: Also in this aspect the conditions are met. The floors in the rooms were made of so called Sorel cement (mortar with magnesium oxide additive, and wood-chip filler). In the restoration of the villa in 1980s the Sorel cement was replaced by the concrete slab reinforced with wire mesh which has similar thermal accumulation properties. The flooring was chosen with regard to the purpose of each room: travertine (from the Tivoli region, Italy), concrete slab, ceramic tiles, and in the living rooms was DLW linoleum (Germany). After 1945 the DLW linoleum was replaced by Xylolite which was again in the restoration in the years 2010-2012 replaced by linoleum with PUR coating. The composition of these layers is able to accumulate sun heat in 
winter and to reradiate the heat at night. In summer these layers can transfer the cold from the northern zone. [5] [6]

In the living space there are also the wooden elements (original ebony wood forming the semicircle wall in the dining part which was in 1981 - 1985 replaced by elements covered by zebrawood veneer) and stone (the onyx wall - was mined from the Atlas Mountains in North Africa) which are capable to accumulate the heat. As it will be visible in the following simulation, we may say that in winter the onyx partition works as a Trombe wall. (Ground plan of the first floor represents Fig. 4 on the previous page.) [5] [6]

Another interesting fact is that there is an air cavity along the whole north-east wall at the level of the second floor which separates the retaining wall and the wall of the rooms. This cavity obviously helps to insulate the building. Moreover the walls at this side of building are massive $(600 \mathrm{~mm}$ or more). The walls are made from bricks and the external walls are clad with insulation boards from so called Torfoleum (impregnated pressed peat board with jute fibre and cattle hair) of $50 \mathrm{~mm}$ (there are two boards of $25 \mathrm{~mm}$ fixed in overlapping bonding). The building has insulated external walls of roughly $330 \mathrm{~mm}$, $370 \mathrm{~mm}$ and $420 \mathrm{~mm}$ width. The non-standard dimension was achieved probably due to the use of the so called German format bricks of the dimensions: 240/115/71 mm (while the dimension of classic burnt clay brick is 290/140/65 mm). The German format of bricks (today known as "Normalformat") was produced by all Brno brick works. The composition of one of the perimeter walls is shown in Figure 5. [5] [6]

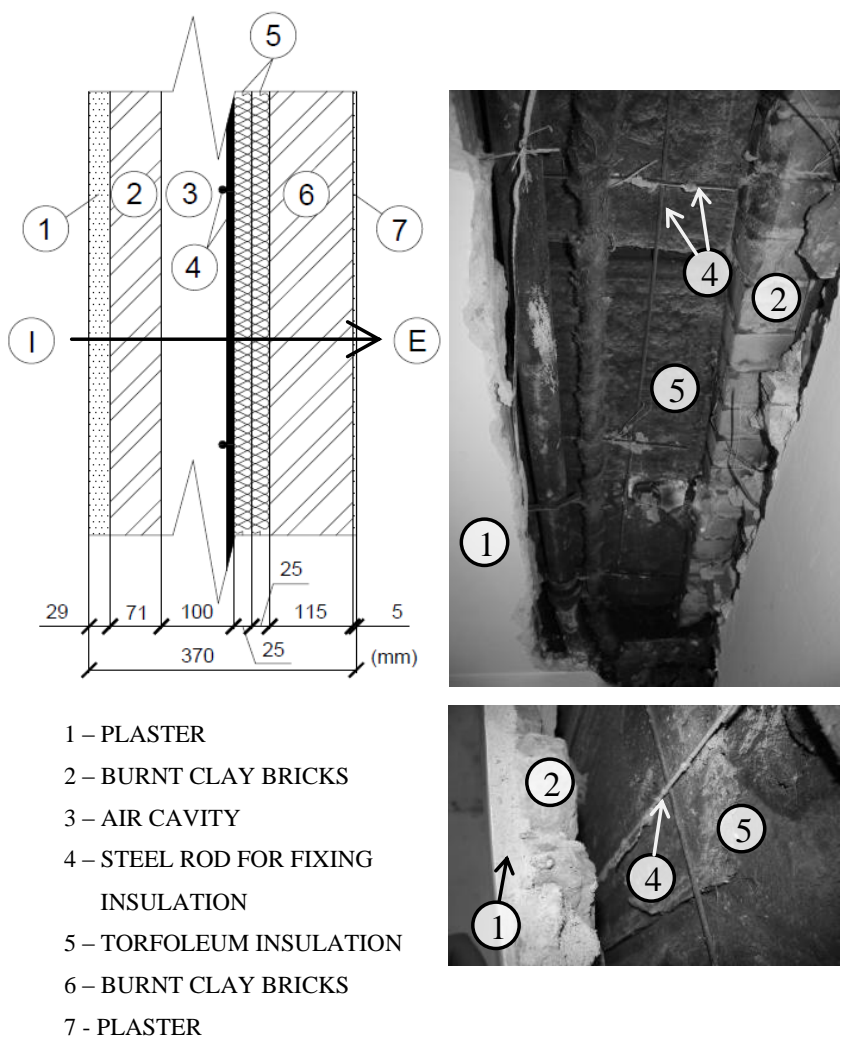

Figure 5. The scheme of wall composition with the with of $370 \mathrm{~mm}$ (on the left), photography of uncovered part of the wall under restoration in 2010 2012 (on the right) [source: author]

The largest window panes in the living space are from glass of $10 \mathrm{~mm}$. The glass is of a similar composition as crystal. [5]

5) The dimension and orientation of glazing: Fig. 6 represents a model of Villa Tugendhat from the east (on the left above) and from the west (on the right below). The model shows that the building has a compact form and the largest glazing is placed on the south-east and south-west facade. Also the winter garden is oriented to the south-east. While the northeast (to the street Černopolní) and north-west facades have a minimum of glazing and the windows are small in dimension. [6]

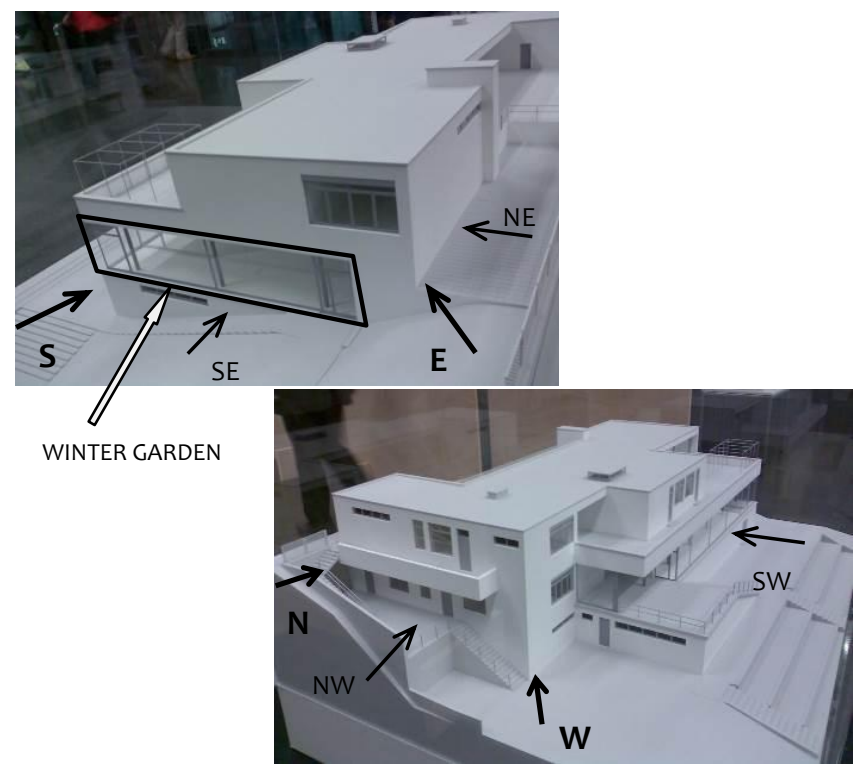

Figure 6. Model of Villa Tugendhat (the exhibition in NTK [National Technical Library] in Prague, 2010) east (left above) and west elevation (right below) [source: author]

\section{Creation of Model for the Numerical Simulation}

To verify our hypothesis that Villa Tugendhat uses the principles of passive solar architecture, a BSim simulation of incident solar radiation in the living space was conducted.

First it was necessary to create a geometric model of the villa. As the loadbearing system of the building is a steel skeleton, which allowed the architect to design open plan, the individual floors do not have the same plan layout (different layout of walls); therefore the creation of a complete geometrical model of the villa in the BSim software was considerably complicated (see Fig. 7 up). Thus it was created a simplified model for simulation incident solar radiation which covers only the main living space ( 1 Floor) in connection to the adjacent rooms (see Fig. 7 down). The composition of the structure was indicated by in situ inspection, also from the materials published about the restoration [5] and last but least by the estimation (based on the total width of the structure and used materials). 


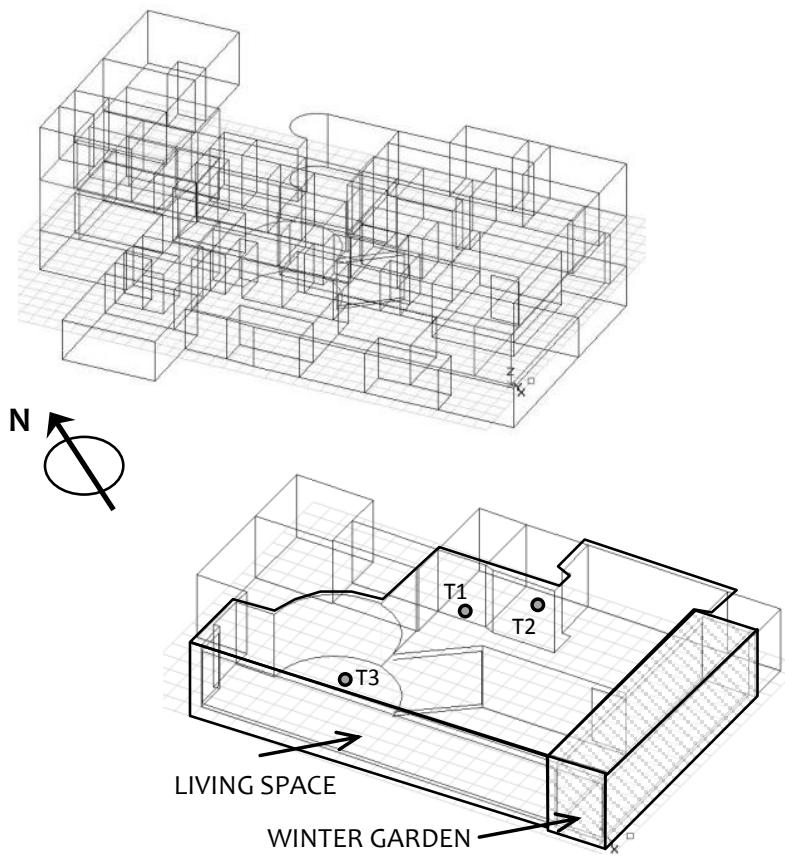

Figure 7. Complete geometric model of the villa in the BSim software (up), simplified geometric model of the living space and the adjacent winter garden on the first floor, indicating the temperature data loggers T1 - T3 (down). [source: author]

The simulation was based on the weather data from the closest meteorological station in Brno - Tuřany (data format TRY). The weather data of the test reference year (TRY) represent average outdoor air temperatures taken over the last 15 years.

\section{Model Validation}

In order to ensure the information value of the simulation, the results were validated by the measured data. The first graph (Fig. 8) shows four runs of outdoor temperature from the period from 12. 7. to 20. 7. 2009: the temperature from the BSim software - weather data of the reference year (Ext_Bsim), temperature measured by the data logger placed on the east side of the building ( $\mathrm{t}$-ext_TZB), temperature measured by the data logger placed on the south-west side of the building (t_T12(ext)_PST) and corresponding temperature measured at the Brno - Turany station (t_ext_Tuřany_aktu) [10].

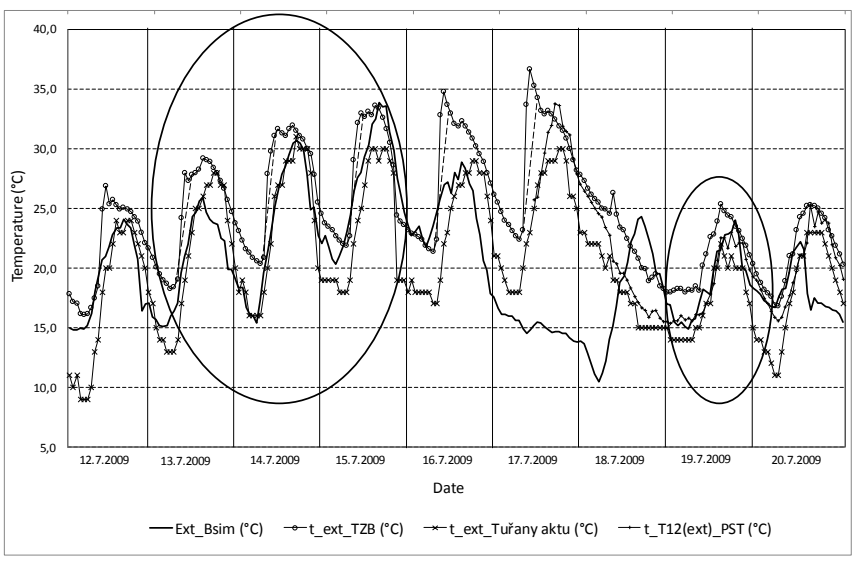

Figure 8. Graph of outdoor temperature curves from data loggers and from BSim in summer season [source: author]

When analysing the data it was found out that the data logger (t_ext_TZB) was between $7-11$ o'clock influenced by the solar radiation which is obvious also in the graph in Fig. 8. The presupposed temperature course without the solar radiation is plotted in the graph in the dashed line. The ellipses indicate the course of temperatures in the days showing the highest correspondence. To validate the course of the inside temperatures in the living space it was chosen the day 19. 7. 2009, as it displays the highest correspondence between the weather data of the referential year (BSim) and the real measured weather data.

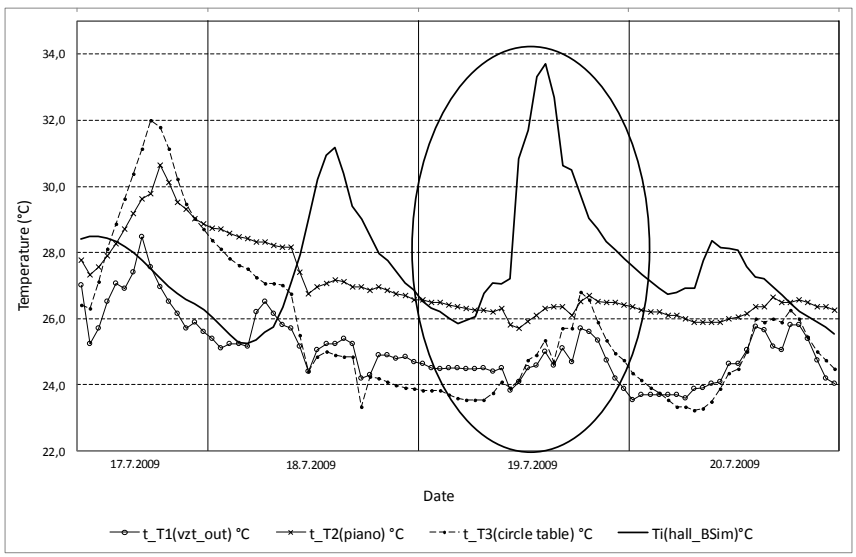

Figure 9. Graph of the indoor temperature course in the living space measured by the sensors $\mathrm{T} 1-\mathrm{T} 3$ and the indoor temperatures indicated by the simulation in the BSim software [source: author]

The graph in Fig. 9 indicates the course of the indoor temperatures measured by the data loggers T1 - T3 and the course of the indoor temperature simulated in the BSim software. The sensors T1 a T3 were placed approximately 0.5 $\mathrm{m}$ above the floor, the sensor $\mathrm{T} 2$ was placed approximately 0.1 $\mathrm{m}$ below the ceiling (see Fig 7 down). The floor-to-ceiling height of the living space is $3.21 \mathrm{~m}$. The courses of temperature from the data loggers $\mathrm{T} 1-\mathrm{T} 3$ show the heat gradient with the height of the room. If we focus on the selected reference day 19.7. 2009, it can be seen - in spite of the close correspondence of climatic data - a considerable difference between the simulated indoor temperature and the real, measured temperature. This difference rises to the maximum of $7.4{ }^{\circ} \mathrm{C}$. The difference is probably caused by the following data: the simulation is unable to take into consideration the shading provided by the deciduous trees planted in the southeast side of the building (next to the winter garden); also it was not possible to simulate the shading by the retractable canvas awnings on the southwest side. Further cause of the difference might be generated by the fact that the BSim software sets the indoor temperature $T_{i}$ in the centre of the space volume while the data loggers were distributed all over the living space area, and at different heights. The actual course of temperatures corresponds with the course of measured temperatures, therefore we can proclaim this model sufficiently valid for the incident solar radiation simulation which allows us to prove the presence of passive solar architecture. In case of using the present model for optimization of the indoor climate 
parameters in the living space, it would have to be further validated and specified in order to attain better correspondence of the results; or it would have to be used other simulation software.

\section{E. Simulation of Incident Solar Radiation in the Living Space of Villa Tugendhat}

The simulation of incident solar radiation represents the days of winter and summer solstice $\left(21^{\text {st }}\right.$ of December and $21^{\text {st }}$ of June), when the sun reaches its lowest (in winter) and highest point (in summer) in the sky at noon.

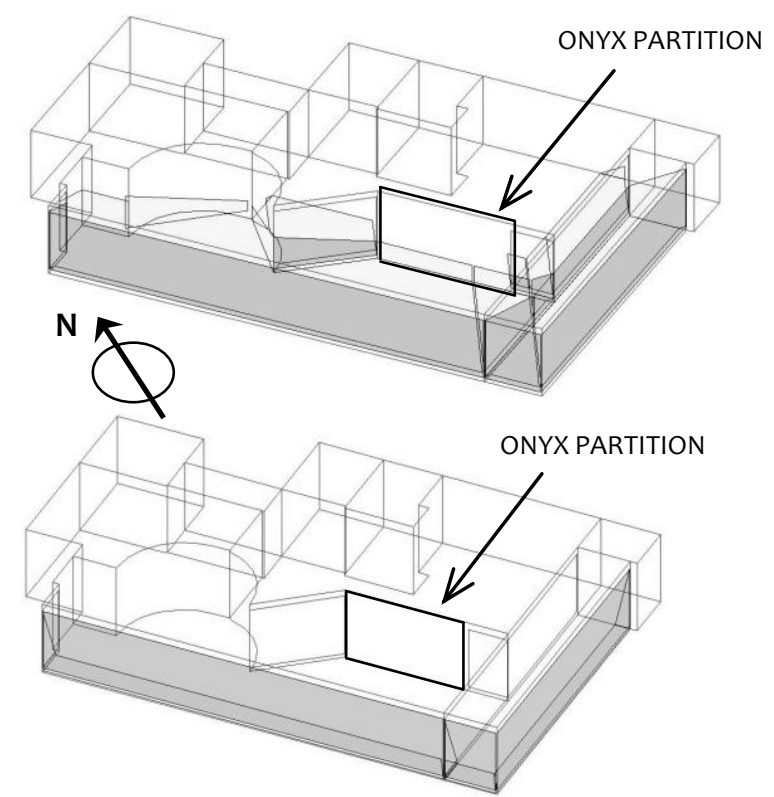

Figure 10. Simulation of the sun exposure in the living space: above $21^{\text {st }}$ of December at 12.00 a.m., below $21^{\text {st }}$ of June at 12.00 a.m. [source: author]
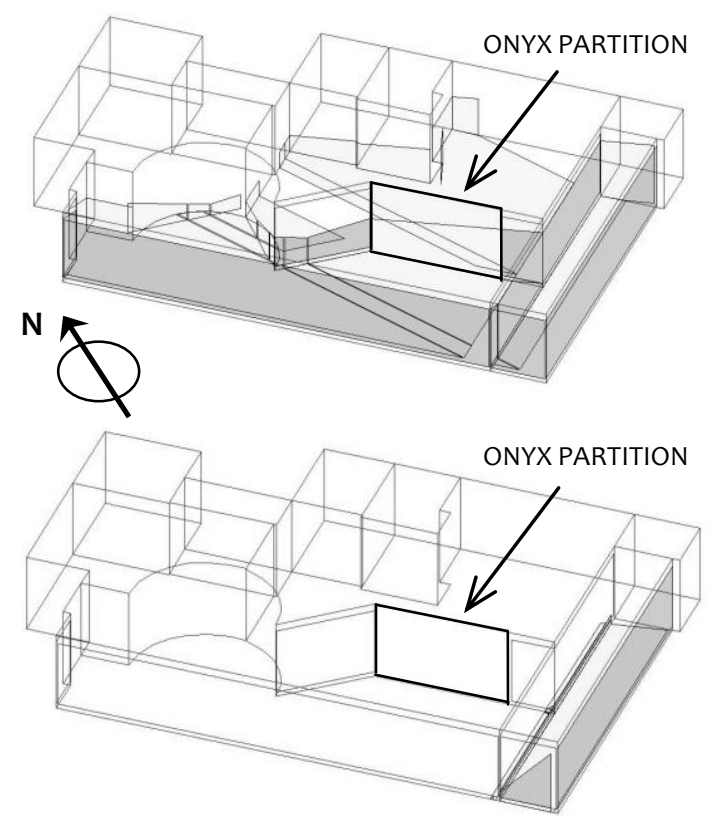

Figure 11. Simulation of sun exposure in the living space: above $21^{\text {st }}$ of December at 9.00 a.m., below $21^{\text {st }}$ of June at 9.00 a.m. [source: author]
The simulation clearly shows in Fig. 10 and 11 that the living space in the winter moths utilizes maximally the solar gains and the onyx wall is placed so that it may store the solar energy during the day; while in the summer months the sun almost does not shine into the living space (although the simulation does not include the shading elements).

\section{CONCLUSION}

Villa Tugendhat was precocious at the time of its erection as the skeleton structure, specially imported materials, and technical equipment were without parallel. As we have seen in this paper its design is optimized and there are used the same principles of solar architecture that are the basics of the contemporary low-energy, passive, and zero-energy houses.

As mentioned above Villa Tugendhat possesses a range of technical specifics. Further research of the unique air conditioning system will be introduced in forthcoming papers.

\section{ACKNOWLEDGMENT}

This article was supported by specific research VG FAST 2010 - project no. 343 - Use of passive solar energy in a historic building. Article was also supported by the South Moravian Centre for International Mobility in program "Brno Ph.D. talent".

Finally, I would like to thank for cooperation to Miroslav Charvát (the technician in the villa Tugendhat) and Ing. arch. Iveta Černá (the head of The Tugendhat House department).

\section{REFERENCES}

[1] Hrabová, M. The Grammar of Beauty. Villa Tugendhat [online]. (C) 2010-2014, [cit. 31 ${ }^{\text {st }}$ May 2014]. Available: <http://www.tugendhat.eu /data/Vila_Tugendhat_Hrabova_Architekt_Gramatika_krasy.pdf $\rangle$

[2] BAM.Brno.cz. Mies van der Rohe Ludwig. Brno Architecture Manual [online]. (C) 2009-2014, [cit. 31 ${ }^{\text {st }}$ May 2014]. Available: <http://www.ba m.brno.cz/architekt/58-ludwig-mies-van-der-rohe>

[3] Atelier Zidlicky. Villa Tugendhat, Photogallery 2012 [online]. (C) 20102014, [cit. $31^{\text {st }}$ July 2012]. Available: <http://www.tugendhat.eu/cz/fotog alerie/fotogalerie-2012.html>

[4] Collective of authors. Great Villas of Brno. Prague: FOIBOS a. s., 2008. 177 p. ISBN 80-903661-5-5

[5] Atelier Zidlicky. Villa Tugendhat [online]. (C) 2010-2014, [cit. $31^{\text {st }}$ July 2012]. Available: <http://www.tugendhat.eu>

[6] Maurerová L., Hirš J. "Elements of Passive Solar Architecture in Villa Tugendhat" Proceedings of the $2^{\text {nd }}$ Annual International Conference on Architecture and Civil Engineering (ACE 2014). Singapore: Global Science and Technology Forum (GSTF), 2014. pp. 420 - 424. ISSN 2301-394X

[7] Wikipedia, The Free Encyclopedia. Sokrtes' house [online]. (C) 2011, last revision $27^{\text {th }}$ April 2013 [cit. $31^{\text {st }}$ July 2012]. Available: <http://cs.wikipedia.org/wiki/Sokratův_dům>

[8] Schleger E. Greenlab [online]. (C) 2008, last revision $21^{\text {st }}$ November 2009 [ cit. $31^{\text {st }}$ July 2012].]. Available: <http://www.greenlab.cz/cs/kucharka/dispozice/>

[9] Danish Building Research Institute Aalborg University Copenhagen [online]. last modified $21^{\text {st }}$ February 2013 [cit. 31 ${ }^{\text {st }}$ July 2012]. Available: 〈http://www.bsim.dk>

[10] The Weather Channel, LLC. Weather Underground [online]. (C) 2014, [cit. $31^{\text {st }}$ July 2012]. Available: 〈http://www.wunderground.com> 


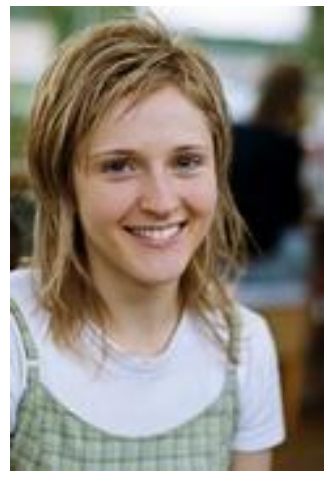

L. Maurerová was born in August 1984 in Nové Město na Moravě, Czech Republic. In 2008 she graduated from the Faculty of Civil Engineering, Brno University of Technology, Czech Republic, in Building Structures, specialization Building Services. She is an assistant at the Institute of Building Services of the Faculty of Civil Engineering, Brno University of Technology, Czech Republic, as well as she is an PhD. student there, specializing in historical systems of HVAC. Her research includes the fields of documentation and optimization of HVAC systems in historical buildings, the use of passive solar energy and shading, building energy, energy certification of buildings.

Mrs. Maurerová is a member of Society of Environmental Engineering (STP) and also a member of IBPSA-CZ (International Building Performance Simulation Association - Czech Republic).

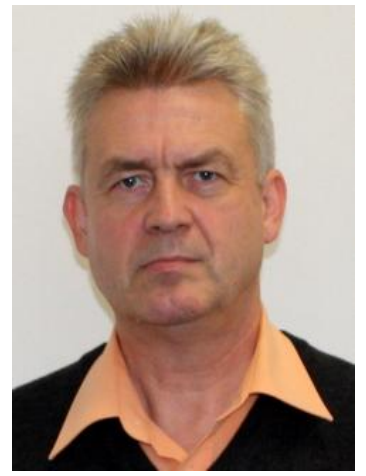

J. Hiř̌ was born in October 1957, in Vimperk, Czech Republic; graduated from the Faculty of Civil Engineering, Brno University of Technology, Czech Republic, in the field of Building Structures, specialization Building Services; in 2001 defended his doctoral thesis, and in 2005 became Associate Professor.

He is the head of the Building Services Institute at the Faculty of Civil Engineering, Brno University of Technology, Czech Republic, and simultaneously is a chartered engineer in the field of Energy certification of buildings, Environmental engineering and Building services systems. As the head of national research group in the field the Research of Building Services has taken part in the projects IEA ECBCS Annex 50, IEA ECBCS Annex 56, Smart Regions and BIM.

Assoc. Prof. Hirš is a member of IBPSA-CZ, member of the Board of Society of Enviromental Engineering (STP), as well as the chairman of the Brno Regional Centre of STP 